\title{
Review Sistematik: Identifikasi Bahaya Paparan Debu Silika pada Pekerja Tambang
}

\author{
Amelia Nurridha Putri ${ }^{1}$, Asni Marlia ${ }^{2}$, Emeralda Cintya Fikrotul Mar'ah ${ }^{3}$, \\ Farizah Idzni Haibati Suswoyo ${ }^{4}$, Muhammad Azmi Hanief ${ }^{5 *}$, Vike Anggrit Firdaus ${ }^{6}$ \\ 1,2,3,4,5,6Program Pendidikan Dokter, Fakultas Kedokteran, Universitas Muhammadiyah Malang
}

\begin{abstract}
ABSTRAK
Pneumokoniosis merupakan penyakit sistemik akibat kerja yang umumnya bermanifestasi sebagai fibrosis difus paruparu yang disebabkan oleh inhalasi debu silika jangka panjang dalam proses produksi, silikosis merupakan salah satunya. Studi ini bertujuan untuk mengidentifikasi bahaya paparan debu silika pada pekerja tambang dengan menggunakan beberapa kajian literatur melalui review sistematik yang diperoleh dari 36 sumber referensi. Beberapa kriteria inklusi yang telah digunakan adalah artikel penelitian kesehatan atau terkait yang dipublikasikan pada rentang tahun 2009-2019 dan artikel penelitian yang memuat topik tentang identifikasi bahaya paparan debu silika terhadap pekerja tambang. Hasil tinjauan pustaka menjelaskan bahwa pekerja penambang memiliki resiko tinggi untuk terjadinya silikosis dikarenakan paparan silika. Menghirup debu ini menimbulkan bahaya karena kandungan kristal silikanya yang tinggi jika mengendap di paru-paru dan dapat menimbulkan silikosis. Silika kristal juga telah diklasifikasikan sebagai karsinogen manusia. Kristal silika dalam masuk ke dalam paru-paru melalui tiga jalur paparan potensial diidentifikasi yaitu iradiasi eksternal, inhalasi debu granit, dan paparan radon. debu silika yang berasal dari pertambangan granit juga menyarankan agar menggunakan masker filter, dikarenakan masker tersebut dapat mengurangi jumlah debu hingga sebanyak dua kali lipat. Pada kesimpulan, pajanan debu silika terkait pekerjaan menyebabkan penyakit paru serius yaitu silikosis yang bersifat irreversible dan sampai saat ini belum ada perawatan yang efektif. Diperlukan tindakan pencegahan yang efektif untuk mengurangi faktor risiko paparan debu silika.
\end{abstract}

Kata kunci: paparan; debu silika; pekerja tambang

\begin{abstract}
Introduction: Pneumoconiosis is an occupational systemic disease that generally manifests as diffuse pulmonary fibrosis caused by inhalation of long-term silica dust in the production process, silicosis is one of them. Purpose: This article aims to identify the dangers of silica dust exposure to mine workers. Method: This study uses several literature studies through systematic review obtained from 36 reference sources. Some inclusion criteria that have been used are health research or related research articles published in the 2009-2019 range and research articles that contain topics on the identification of hazards of exposure to silica dust to mine workers. Results: Literature review results explain that miners have a high risk of silicosis due to silica exposure. Inhalation of this dust poses a danger because of its high silica crystal content if it settles in the lungs and can cause silicosis. Discussion: Crystal silica has also been classified as a human carcinogen. Silica crystals entering the lungs through three potential exposure pathways are identified namely external irradiation, inhalation of granite dust, and radon exposure. silica dust from granite mining also suggests using a filter mask, because the mask can reduce the amount of dust up to twice as much. Conclusion: In conclusion, occupational exposure to silica dust causes serious lung disease that is silicosis which is irreversible and so far there has been no effective treatment. Effective precautions are needed to reduce the risk factors for silica dust exposure.
\end{abstract}

Keywords: exposure; silica dust; mine workers

*Korespondensi penulis:

Nama : Muhammad Azmi Hanief

Instansi : Fakultas Kedokteran Universitas Muhammadiyah Malang

Alamat : Jl. Bendungan Sutami 188A Malang, Jawa Timur, Telp.: +62-341-552443/+62-341-582260

Email : azmi.hanief25@gmail.com 


\section{Pendahuluan}

Silika adalah bahan mineral, terdiri dari satu atom silikon dan dua atom oksigen (Sio2), dengan titik leleh $1600^{\circ} \mathrm{C}$. Silika adalah zat padat yang bersifat tidak berbau, tidak berwarna, tidak mudah terbakar. Silika merupakan mineral alami yang menyumbang 59\% dari massa kerak bumi dan merupakan konstituen utama dari batu yaitu $>95 \%$. $^{1-3}$

Debu silika dapat menyebabkan beberapa penyakit jika terhirup berulang kali. $^{4}$ Pneumokoniosis merupakan penyakit sistemik akibat kerja yang umumnya bermanifestasi sebagai fibrosis difus paru-paru yang disebabkan oleh inhalasi debu silika jangka panjang dalam proses produksi, silikosis merupakan salah satunya. $^{5}$

Silikosis merupakan salah satu jenis pneumokoniosis yang disebabkan oleh penghirupan debu silika dengan ukuran dibawah $10 \mu \mathrm{m}$ dan dianggap sebagai debu aktif yang secara biologis dapat mengendap di bronkus, kelenjar getah bening, dan /atau parenkim paru, dengan atau tanpa disfungsi pernapasan terkait. ${ }^{6-}$ ${ }^{8}$ Silikosis adalah penyakit yang berbahaya dan tidak dapat disembuhkan karena dapat menybabkan kerusakan permanen pada paru dan merusak kapasitas paru. Saat ini belum ada perawatan yang efektif. ${ }^{9}$ Pada tahun 1997 , kristal silika terbukti menjadi bahan karsinogen pada manusia, terutama kanker paru karena inhalasi berlebihan partikel kristal silika dapa merangsang makrofag dan neutrofil di jaringan paru untuk menghasilkan berbagai sitokin inflamasi, kemokin dan Reaktive Oxygen Species (ROS). ${ }^{2,10}$ Ada tiga bentuk silicosis, diantaranya: silikosis kronis, accelerated silicosis, dan silikosis akut, faktor yang mempengaruhi yaitu lama pajanan dan besarnya pajanan,

Paparan debu silika adalah masalah kesehatan global terkait pekerjaan menjadi dan topik utama dalam beberapa tahun terakhir. Di Cina insiden silikosis meningkat sejak 2008, dengan >10.000 kasus dilaporkan tiap tahunnya. Sedangkan di Amerika Serikat diperkirakan terdapat 2 juta orang dan 3 juta orang di Eropa terpajan debu silika di lingkungan kerjanya. ${ }^{11-13}$

Telah diketahui bahwa pajanan silika yang terkait dengan pekerjaan berhubungan dengan meningkatnya mortalitas penyakit pernapasan akibat kerja. Banyak proses dan kegiatan industri seperti pekerjaan konstruksi, pertambangan, pembuatan terowongan, seni, kerajinan tangan dan patung, dan perhiasan yang melibatkan paparan inhalasi silika. ${ }^{11}$ Langkahlangkah untuk mengurangi inhalasi silika yang dilakukan berdasarkan struktural, lingkungan dan perbaikan teknis di tempat kerja dapat mengurangi angka kejadian penyakit tersebut. ${ }^{14}$ Berdasarkan paparan tersebut, artikel ini memuat identifikasi bahaya paparan debu silika terhadap pekerja tambang.

\section{Metode}

Studi ini menggunakan beberapa kajian literatur melalui review sistematik yang diperoleh dari 38 sumber referensi melalui mesin pencari manual pada database Science Direct, Google Scholar, PubMed, Proquest Health and Medical Complete, Elsevier, Cochrane dari tahun 2015 sampai dengan tahun 2020. Beberapa kriteria inklusi yang telah digunakan adalah sebagai berikut: 1) Artikel penelitian kesehatan atau terkait yang dipublikasikan pada rentang tahun 2015-2020, 2) Artikel penelitian yang memuat topik tentang identifikasi bahaya paparan debu silica pada pekerja tambang.

Berdasarkan kajian literatur dari 38 artikel yang diperoleh dari beberapa database, terdapat 15 artikel yang memenuhi kriteria inklusi. Selanjutnya 15 artikel tersebut dikaji lebih lanjut untuk mengidentifikasi bahaya paparan debu silika pada pekerja tambang. Artikel tersebut berbasis evidence-based yang dibutuhkan untuk menambah pengetahuan 
tentang identifikasi bahaya paparan debu silica pada pekerja tambang.

\section{Hasil dan Pembahasan}

Silikosis adalah penyakit paru interstitial yang progresif disebabkan oleh inhalasi silika kristalin dan bersifat ireversibel.15 Prevalensi terjadinya silikosis pada tahun 1996 dan 2017, terdapat 216 kasus silikosis yang dilaporkan. Kisaran usia mereka yang dilaporkan adalah 61 tahun (23-89), dengan mayoritas (98\%) adalah laki-laki. Di semua industri, 65\% dari kasus didiagnosis pada individu usia kerja ( $<65$ untuk pria dan $<60$ untuk wanita). ${ }^{16}$

Menurut penelitian Carneiro et al, 2017, dalam penelitiannya menyatakan bahwa prevalensi silikosis dan gangguan pernapasan, sangat tinggi di sekelompok pengrajin kristal yang terpapar dengan kadar debu silika yang sangat tinggi, kemudian morbiditas lainnya yang berhubungan dengan silika seperti penyakit mikobakteri dan penyakit autoimun, serta kematian akibat silicosis. ${ }^{17}$ Jumlah insiden kasus silikosis telah meningkat dari 14,5 ribu pada tahun 1990 menjadi 23,7 ribu pada tahun 2017. Silikosis juga merupakan salah satu insiden penyakit akibat kerja tertinggi di banyak negara berkembang, termasuk negara China. Lebih dari 10.000 kasus silikosis baru telah dilaporkan oleh badan manajemen kesehatan nasional China setiap tahun sejak 2010. ${ }^{18}$

Pekerja penambang memiliki resiko tinggi untuk terjadinya silikosis dikarenakan paparan silica. ${ }^{19}$ Perbedaan risiko silikosis bagi pekerja di lingkungan kerja yang berbeda menandakan bahwa risiko silikosis dapat dipengaruhi oleh keadaan industri, komposisi partikel atau struktur paparan debu silika. ${ }^{18}$ Pekerjaan sebagai karyawan di industri granit memiliki risiko akan kesehatan dan keselamatannya dimana prosedur untuk mengekstraksi dan memproses granit dapat menghasilkan sejumlah besar debu granit di lingkungan kerja. Menghirup debu ini menimbulkan bahaya karena kandungan kristal silikanya yang tinggi jika mengendap di paruparu dan dapat menimbulkan silikosis. Silika kristal juga telah diklasifikasikan sebagai karsinogen manusia oleh Badan Penelitian Kanker dan terkait dengan kanker paru-paru, ${ }^{20}$ ini sesuai dengan penelitian yang dilakukan oleh Barber et al pada tahun 2018 juga mengatakan bahwa lingkungan pekerjaan mempengaruhi tingkat terjadinya silikosis. Barber et al juga menemukan bahwa dalam beberapa kelompok industri, khususnya pengecoran dan konstruksi, ada peningkatan terjadinya silikosis dengan kategori usia meningkat. Sebaliknya, dalam penggalian, pembuatan terowongan dan kelompok industri keramik / bata dengan jumlah kasus yang jauh lebih rendah. ${ }^{16}$

Merokok merupakan salah satu faktor resiko dari silikosis, penelitian yang dilakukan oleh putu dimana didapatkan $83,6 \%$ pekerja dengan kebiasaan merokok. Studi telah menunjukkan bahwa perokok yang terpajan debu silika lebih sering mengalami silikosis secara klinis dibandingkan dengan yang bukan perokok yang terpajan dalam dosis yang sama. Berdasarkan hal tersebut, maka perlu diberikan edukasi kepada pekerja mengenai pentingnya berhenti merokok dalam upaya mengurangi dampak buruk pajanan debu silika terhadap kesehatan. ${ }^{12}$ Hal ini didukung oleh penelitian yang dilakukan oleh Wang et al 2019, yang menyatakan bahwa dengan merokok dapat berperan dalam terjadinya dan pengembangan silikosis sehingga berhenti merokok bisa membantu mengurangi risiko silikosis bagi pekerja yang terpajan silika. ${ }^{18,21}$

Status nutrisi dapat memengaruhi sistem imun tubuh seseorang. Tanpa nutrisi yang adekuat, sistem imun mengalami kekurangan komponen yang dibutuhkan untuk menghasilkan respons imun yang efektif terhadap infeksi atau penyakit. $^{12}$ 
Lama kerja dapat menjadi faktor resiko bagi para pekerja, menurut Kohli et al, 2017 dalam penelitiannya yang meneliti 99 Pasien yang dirujuk ke Departemen Radiodiagnosis dengan dugaan penyakit paru akibat kerja dan 8 pasien didiagnosis sebagai silikosis, mengatakan bahwa rata-rata usia pekerja memulai untuk berkerja ialah 18 tahun dan $75 \%$ pekerja yang didiagnosis menderita silikosis telah bekerja di unit pemecah batu selama 18-30 tahun. ${ }^{22}$ Hal ini juga didukung oleh penelitian yang dilakukan Wang et al pada tahun 2019 bahwa lama paparan harus di bawah 10 tahun untuk penambang logam dan 40 tahun untuk pekerja pabrik tembikar bila terpapar $0,05 \mathrm{mg} / \mathrm{m} 3$ untuk menjaga risiko seumur hidup dalam $0,1 \% .{ }^{18}$ Menurut penelitian Normohammadi et al, 2016 mengatakan bahwa konsentrasi debu silika yang terhirup oleh individu yang terpapar merupakan faktor resiko terjadinya silikosis. Selain itu juga durasi pajanan adalah faktor risiko paling kuat untuk terjadinya silicosis. $^{2}$

Silika atau Silikon dioksida (SiO2) adalah senyawa anorganik yang terdiri dari atom silikon dan dua atom oksigen. ${ }^{21}$ Paparan debu respirable (RD) yang terdiri dari kristalin silikon dioksida (SiO2) merupakan ancaman dalam bidang pertambangan, peledakan pasir, pekerjaan pengecoran, pertanian, dan konstruksi yang nantinya dapat mengakibatkan silicosis. ${ }^{9}$ Silika tidak berwarna, tidak berbau, dan tidak mudah terbakar dan merupakan sekitar 25\% dari lapisan bumi. ${ }^{21}$ Lapisan bumi terdiri dari banyak silika, terutama terdiri dari debu kuarsa. Paparan silika kristal respirable dapat menyebabkan silikosis, tuberkulosis paru, penyakit paru obstruktif kronik, kanker paru, gangguan autoimun dan penyakit ginjal kronis. ${ }^{15}$

Kegiatan penambangan seperti pengeboran, pemotongan, dan penghancuran mineral dan batu yang mengandung kristal silika melepaskan silika bebas di lingkungan kerja. Penghirupan dan pengendapan partikel debu silika menghasilkan peradangan persisten bersama dengan pembentukan granuloma dan fibrosis jaringan paru-paru, mengakibatkan pengurangan kapasitas fungsional paru-paru. Debu silika kurang dari $5 \mu \mathrm{m}$ dapat dihirup ke dalam saluran pernapasan perifer sehingga mengakibatkan akumulasi di paru-paru menyebabkan berbagai patologi, termasuk fibrosis, yang pada gilirannya akan mengurangi kapasitas paru secara permanen dan kemampuan paru untuk bertukar gas. ${ }^{9}$

Silika dapat ditemukan dalam dua bentuk umum: kristal dan non-kristal. Ada beberapa bentuk kristal silika, yang meliputi $\alpha$-kuarsa, kuarsa, tridimit, kristobalit, keatit, coesit, stishovite dan moganite. ${ }^{21}$ Menurut American Conference of Governmental Industrial Hygienists (ACGIH), batas paparan 8 jam kerja untuk silika adalah $0,025 \mathrm{mg} / \mathrm{m} 3$. Di Iran, Kementerian Kesehatan juga telah menetapkan batas ini menjadi $0,025 \mathrm{mg} / \mathrm{m} 3 .^{21}$ Berdasarkan penelitian yang dilakukan oleh Golbabaei et al pada tahun 2019 yang meneliti tentang kadar debu total dan yang dapat terhirup dan kandungan silika kristalin pada tahun 2016-2017 di enam tambang silika Iran didapatkan ingkat debu total rata-rata tertinggi di tambang yang diteliti, 17,1 \pm $3,9 \mathrm{mg} / \mathrm{m} 3$, diamati di unit peremukan, dan terendah, 3,1 $\pm 0,9 \mathrm{mg} / \mathrm{m} 3$, dimiliki oleh unit manajemen/ administrasi serta tingkat debu respirasi rata-rata tertinggi di tambang adalah $10,4 \pm 3,2 \mathrm{mg} / \mathrm{m} 3$, yang termasuk dalam unit penghancur, dan yang terendah adalah $1,3 \pm 0,08$ $\mathrm{mg} / \mathrm{m} 3$ dan dimiliki oleh unit manajemen/ administrasi. ${ }^{21}$

Kristal silika dalam masuk ke dalam paru-paru melalui tiga jalur paparan potensial diidentifikasi yaitu iradiasi eksternal, inhalasi debu granit, dan paparan radon. Iradiasi eksternal dapat terjadi di semua lingkungan kerja, karena pabrik dalam penelitian ini terletak di batholith granit. Penghirupan debu granit dipertkirakan terjadi di tempat-tempat di mana ekstraksi dan 
pengolahan blok granit terjadi seperti pabrik pengolahan dan bengkel kerajinan tangan, sedangkan paparan radon diperkiranakn berada dalam lingkungan tertutup, seperti kantor dan pabrik pemrosesan. ${ }^{20}$

Dalam penelitian yang dilakukan oleh Wang et al, 2019 mengatakan bahwa untuk mengetahui risiko silikosis di antara yang terpajan silika pekerja dalam situasi industri yang berbeda, dengan mengamati hubungan paparanrespons kuantitatif antara paparan silika yang dapat dihirup secara kumulatif dan silikosis di antara 39.808 pekerja yang terpapar silika di tambang logam dan pabrik tembikar dengan penilaian paparan silika individual yang terperinci. Berdasarkan data 9.377 silikosis, kami menemukan bahwa risiko silikosis lebih tinggi untuk pekerja di tambang logam daripada di pabrik tembikar ketika tingkat paparan silika serupa. SDM silikosis adalah 1,09 $(1,08-1,09)$ di tambang logam dan 1,03 (1,02-1,04) di pabrikpabrik tembikar ketika setiap peningkatan CDE 1 mg / m3-tahun. Risiko kumulatif silikosis adalah $6,3 \%, 15,9 \%$, dan $98,4 \%$ untuk penambang logam dan $0,6 \%, 11,0 \%$, dan $41,8 \%$ untuk pekerja di pabrik tembikar ketika mereka terpapar 0,05 $\mathrm{mg} / \mathrm{m} 3,0,1 \mathrm{mg} / \mathrm{m} 3,0,35 \mathrm{mg} / \mathrm{m} 3$ silika terhirup selama 45 tahun. ${ }^{18}$

Dalam mendiagnosis silikosis tidak hanya dengan menggunakan anamnesis dan pemeriksaan fisik, pada penelitian yang di lakukan oleh supreti mengatakan bahwa gejala klinis silikosis berkembang setelah periode paparan silika dan pasien tetap tidak menunjukkan gejala meskipun rontgen dada telah menunjukkan lesi. ${ }^{22}$

Seperti halnya bentuk-bentuk lain dari pneumokoniosis, misalnya, pneumokoniosis pekerja batu bara, tahap paling awal dari kondisi ini mungkin tidak menunjukkan gejala. ${ }^{23}$ Semua pekerja yang terpapar silika kristalin harus menjalani pengawasan kesehatan seumur hidup dan melakukan rontgen dada awal sebelum berkerja, dengan rontgen dada ulang dilakukan setelah 2-3 tahun. Rontgen toraks harus dilakukan setiap 2-5 tahun sesudahnya. Spirometri dan anamnesis juga harus diperoleh setiap tahun sejak awal pekerjaan dan harus meminta rujukan ke layanan pernapasan spesialis jika ada kelainan yang terdeteksi. ${ }^{23}$ Menurut Rajavel, et al 2020 pada penelitian terbarunya mengatakan bahwa pemeriksaan dan investigasi klinis seperti Spirometri, $\mathrm{x}$-ray dada dan mikroskopis dahak harus dilakukan pada frekuensi reguler untuk pekerja tambang, dalam rangka penilaian morbiditas pernapasan pada tahap awal. ${ }^{15}$

HRCT dada tidak direkomendasikan sebagai alat diagnostik dalam mendiagnosis silikosis, karena dapat mendeteksi nodul paru yang tidak signifikan yang dapat mengakibatkan masalah dalam diagnosis definitif dan mengarah pada pelaporan kasus positif palsu. Penggunaan HRCT dada hanya boleh digunakan untuk kasuskasus tertentu yang membutuhkan karakterisasi lebih lanjut. Oleh karena itu X-Ray Chest masih tetap menjadi alat diagnostik utama. (supreti) Namun berbeda dengan yang dikatakan knight dalam penelitiannya bahwa Paparan pertamakali dan usia tetap menjadi prediktor yang kuat sementara deteksi radiologis silikosis pada penambang masih memerlukan perhatian. ${ }^{19}$

Penelitian yang dilakukan oleh Putu menunjukkan hubungan yang bermakna antara pajanan debu silika dan TGF- $\beta 1$ serum ( $\mathrm{r}=0,319$, $\mathrm{p}=0,018)$. Berdasarkan pemeriksaan TGF- $\beta 1$ serum, maka dapat diduga terjadi peningkatan risiko silikosis pada pekerja industri pengolahan batu. Penelitian oleh Miao, dkk.12 menemukan kadar TGF- $\beta 1$ serum pada pekerja kelompok silikosis lebih tinggi dibandingkan kelompok terpajan debu silika lebih dari 1 tahun dengan nilai rerata 29,31 (SB 14,52) pg/ml dibandingkan kelompok kontrol $(23,28$ (SB 12,24)) $\mathrm{pg} / \mathrm{ml}$ dengan nilai $\mathrm{p}<0,01 .{ }^{12}$ 
Silikosis dapat dibagi menjadi tiga tipe berdasarkan waktu terjadinya, yaitu akut, terakselerasi, dan kronis. Silikosis kronis merupakan silikosis yang paling sering terjadi yang diakibatkan oleh pajanan jangka panjang (biasanya lebih dari 20 tahun) terhadap debu silika. Silikosis terakselerasi terjadi 5-15 tahun setelah terpajan debu silika. Sementara itu, silikosis akut terjadi akibat pajanan jangka pendek terhadap debu silika dalam jumlah besar. Terdapat hubungan yang jelas antara lamanya paparan debu silika dengan kejadian silicosis. ${ }^{12}$

Silikosis adalah penyakit yang tidak dapat disembuhkan yang dapat timbul karena menghirup debu silika kristal terhirup yang menyebabkan peradangan persisten, dan akhirnya, penurunan fungsi paru-paru. Oleh karena itu, kontrol atas silikosis terutama terletak pada pencegahan, yang biasa terjadi pada pekerja industri tambang batu, Nandi et al, 2018 melakukan penelitian pada tahun 2018 untuk menilai kesadaran tentang silikosis di antara 305 pekerja tambang batu dari distrik Jodhpur dan Nagaur di Rajasthan, didapatkan hasil kesadaran tentang istilah silikosis rendah, sekitar $41,2 \%$ di Jodhpur dan $40 \%$ di kabupaten Nagaur. Sehingga disimpulkan bahwa tingkat pendidikan pekerja tambang sangat memengaruhi pengetahuan silikosis di antara mereka. Selain itu, kurangnya kemampuan dalam membaca dan kurang pengetahuan tentang penggunaan tindakan perlindungan dapat menghasilkan efek surplus. Sehingga perlu dilakukan seminar, simposium, dan kamp medis gratis untuk meningkatkan kesadaran tentang penyebab dan komplikasi silikosis di antara pekerja tambang batu. Media komunikasi seperti media, lembaga pemerintah, dan lembaga sosial memainkan peran yang bermanfaat dalam menciptakan kesadaran mengenai silikosis dan bahaya kesehatan kerja lainnya di antara pekerja tambang.

Menurut penelitian Riskiana dan Modjo 2018, dikarenakan pekerja di tambang memiliki resiko terpapar debu batubara yang mana nnatinya akan berpengaruh kepada kesehatan para pekerja, sehingga perlu dilakukan Medical Check Up (MCU) untuk para pekerja agar terdeteksi dini penyakit yang diderita akibat paparan debu batubara. ${ }^{24}$ Didukung oleh penelitian yang dilakukan oleh Kohli et al tahun 2017 menyatakan bahwa Pemeriksaan secara aktif mengenai kesehatan dan pendidikan para pekerja untuk praktik kerja yang aman sangat penting untuk mengurangi angka kematian dan morbiditas pada pekerja dan dapat mendeteksi sebelum muncul penyakit, selain itu dengan melakukan Xray dada rutin akan mendeteksi lesi lebih awal. ${ }^{22}$

Pemakaian masker sebagai APD oleh pekerja sangat dianjurkan sebagai upaya untuk mengurangi masuknya partikel debu ke dalam saluran pernapasan. Berdasar pada penelitian yang dilakukan oleh putu didapatkan hasil sebagian besar pekerja menggunakan APD dengan tingkat penggunaan jarang $(56,4 \%)$. Sementara itu jumlah pekerja yang tidak pernah menggunakan APD adalah sebesar 29,1\%. Penelitian ini mandapatkan hasil kadar debu total pada perusahaan X1 sebesar $1.229 \mathrm{mg} / \mathrm{m} 3, \mathrm{X} 2$ sebesar $639 \mathrm{mg} / \mathrm{m} 3$, dan X3 sebesar 331 $\mathrm{mg} / \mathrm{m} 3 .^{12}$

Penelitian yang dilakukan oleh Tejado et al, 2016 yang melakukan penelitian tentang debu silika yang berasal dari pertambangan granit juga menyarankan agar menggukan masker filter, dikarenakan masker tersebut dapat mengurangi jumlah debu hingga sebanyak dua kali lipat, dimana masker filter mampu mempertahankan hingga 99\% partikel yang memiliki ukuran lebih besar dari dari $1 \mu \mathrm{m}$ (20). Menurut penelitian yang dilakukan oleh Chanvirat et al, 2018 menyatakan bahwa pekerja yang terkena paparan konsentrasi Silika Kristalin Respirable (RCS) < 0,5 $\mathrm{mg} / \mathrm{m} 3$ harus menggunakan perangkat pelindung dengan APF dari 10 (faktor perlindungan yang ditugaskan). filter memiliki 
efisiensi, filter untuk N95, R95 dan P95 partikel ukuran. Penambang batu terkena RCS > 0,5 $\mathrm{mg} / \mathrm{m} 3$, harus menggunakan respirator dengan APF dari 40. Ini termasuk masker wajah penuh dan filter partikel untuk N100, R100, dan P10. ${ }^{9}$

Selain masker, teknologi Helmet-CAM dapat mengurangi paparan debu silika Berdasarkan penelitian yang dilakukan oleh Haas et al pada tahun 2016 mengatakan bahwa terdapat teknologi baru dari Helmet-CAM masih diteliti lebih lanjut untuk mengidentifikasi pekerjaan dan area paparan debu silika yang terhirup dan untuk mengevaluasi potensi efektivitas untuk mengurangi paparan debu silika yang berlebihan dan teknologi Helmet-CAM di harapkan untuk mengurangi paparan debu silika di masa depan. ${ }^{25}$ Menurut Carneiro et al, 2017 prognosis silikosis tergantung pada faktor individu dan jenis paparan silika. Penegakan tindakan yang ketat dan kepatuhan terhadap pengendalian debu tetap merupakan metode terbaik untuk mencegah perkembangan silicosis. ${ }^{17,23}$

\section{Kesimpulan}

Pajanan debu silika terkait pekerjaan menyebabkan penyakit paru serius yaitu silikosis yang bersifat irreversible dan sampai saat ini belum ada perawatan yang efektif. Diperlukan tindakan pencegahan yang efektif untuk mengurangi faktor risiko paparan debu silika. Perlu dilakukan tinjauan melalui pendekatan holistik komprehensif tentang risiko-risiko penyakit akibat kerja yang lain pada pekerja tambang.

\section{Ucapan Terima Kasih}

Kami mengucapkan terima kasih yang sebesar-besarnya kepada dokter pembimbing, Dr. dr. Febri Endra Budi Setiawan, M.Kes, FISPH, FISCM atas dukungan dan bimbingannya selama penulisan artikel ini.

\section{Referensi}

1. Barnes H, Goh NSL, Leong TL, Hoy R. Silica-associated lung disease: An old-world exposure in modern industries. Respirology. 2019;24(12):1165-75.

2. Normohammadi M, Kakooei H, Omidi L, Yari S, Alimi R. Risk Assessment of Exposure to Silica Dust in Building Demolition Sites. Saf Health Work. 2016;7(3):251-5.

3. Omidianidost A, Ghasemkhani M, Kakooei H, Shahtaheri SJ, Ghanbari M. Risk assessment of occupational exposure to crystalline silica in small foundries in Pakdasht, Iran. Iran $\mathbf{J}$ Public Health. 2016;45(1):70-5.

4. Koller MF, Scholz SM, Pletscher C, Miedinger D. Silicosis in Switzerland. Int J Occup Med Environ Health. 2018;31(5):659-76.

5. Liu J, Song HY, Zhu BL, Pan LP, Qian XL. The Effect of Silica Dust Exposure on the Serum Clara Cell Protein 16 Levels in Chinese Workers. Biomed Environ Sci. 2019;32(1):47-50.

6. Garcia DD, Latorre PR, Sultan NM, Yerba OR, Palacios EA, Cano AD. Silicosis: Origins and Consequences. Am J Med Sci Med. 2019;7(3):60-3.

7. Sato T, Shimosato T, Klinman DM. Silicosis and lung cancer: Current perspectives. Lung Cancer Targets Ther. 2018;9:91-101.

8. Jones CM, Pasricha SS, Heinze SB, MacDonald S. Silicosis in artificial stone workers: Spectrum of radiological highresolution CT chest findings. J Med Imaging Radiat Oncol. 2020;64(2):241-9.

9. Chanvirat $\mathrm{K}$, Chaiear $\mathrm{N}$, Choosong $\mathrm{T}$. Determinants of Respirable Crystalline Silica Exposure among Sand-stone Workers. Am J Public Health. 2018;6(2):44-50.

10. Shen T, Sheng L, Chen Y, Cheng L, Du X. High incidence of radiation pneumonitis in 
lung cancer patients with chronic silicosis treated with radiotherapy. J Radiat Res. 2019;61(1):117-22.

11. Wen C, Wen X, Li R, Su S, Xu H. Silicosis in rhinestone-manufacturing workers in South China. Occup Med (Chic Ill). 2019;69(7):475-81.

12. Putu I, Krisnha Wijaya E, Bagus I, Rai N, Andrika IP. Hubungan antara Pajanan Debu Silika dengan Transforming Growth Factorß1 Serum pada Pekerja Industri Pengolahan Batu Association between Silica Dust Exposure and Serum Transforming Growth Factor- $\beta 1$ in Stone Quarry Workers. J Penyakit Dalam Indones. 2019;6(2):64-70.

13. Wu N, Xue C, Yu S, Ye Q. Artificial stoneassociated silicosis in China: A prospective comparison with natural stone-associated silicosis. Respirology. 2020;25(5):518-24.

14. Fan C, Graff P, Vihlborg P, Bryngelsson IL, Andersson L. Silica exposure increases the risk of stroke but not myocardial infarction A retrospective cohort study. PLoS One. 2018;13(2):1-9.

15. Rajavel S, Raghav P, Gupta MK, Muralidhar V. Silico-tuberculosis, silicosis and other respiratory morbidities among sandstone mine workers in Rajasthan- a cross-sectional study. PLoS One. 2020;15(4):e0230574.

16. Barber CM, Fishwick D, Carder M, Van Tongeren M. Epidemiology of silicosis: Reports from the SWORD scheme in the UK from 1996 to 2017. Occup Environ Med. 2019;76(1):17-21.

17. Carneiro APS, Braz NFT, Algranti E, Bezerra OMPA, Araujo NPS, Amaral Eng Hyg LS, et al. Silica exposure and disease in semi-precious stone craftsmen, Minas Gerais, Brazil. Am J Ind Med. 2017;60(3):239-47.

18. Wang D, Zhou M, Liu Y, Ma J, Yang M, Shi $\mathrm{T}$, et al. Comparison of Risk of Silicosis in
Metal Mines and Pottery Factories. Chest. 2020;158(3):1050-1059.

19. Knight D, Ehrlich R, Cois A, Fielding K, Grant AD, Churchyard G. Predictors of silicosis and variation in prevalence across mines among employed gold miners in South Africa. BMC Public Health. 2020;20(1):829.

20. Tejado JJ, Guillén J, Baeza A. Assessment of occupational exposure in a granite quarry and processing factory. J Radiol Prot. 2016;36(3):641-52.

21. Golbabaei F, Gholami A, Teimori-Boghsani G, Yaseri M, Kianmehr M. Evaluation of Occupational Exposure to Silica Dust in Mining Workers in Eastern Iran. Open Environ Res J. 2019;12(1):1-6.

22. Kohli S, Singhal A, Chaudhury B, Kohli R. Silicosis in Stone Crushing Workers-A Retrospective Analysis [Internet]. 2017 [cited 2020 December 10]. Available from: https://www.semanticscholar.org/paper/Sili cosis-in-Stone-Crushing-Workers-A-

Retrospective-Kohli-

Singhal/6fabff86d3a27d46fe7f669ada8ff74 a7eeca435.

23. Nicol LM, McFarlane PA, Hirani N, Reid PT. Six cases of silicosis: Implications for health surveillance of stonemasons. Occup Med (Chic Ill). 2015;65(3):220-5.

24. Rizkiani DO, Modjo R. Health Risk Assessment of Workers at the Mining Company PT. HIJ Site in South Kalimantan: An Overview. KnE Life Sci. 2018;4(5):616.

25. Haas EJ, Willmer D, Cecala AB. Formative research to reduce mine worker respirable silica dust exposure: A feasibility study to integrate technology into behavioral interventions. Pilot Feasibility Stud. 2016;2(1):1-11. 